\title{
RECONSIDERING DUTCH RUPS, GERMAN RAUPE 'CATERPILLAR'1
}

by Michiel de Vaan — Leiden

1 For the etymology of Dutch rups 'caterpillar', De Vries (1971: 597) mentions two different possible etymologies: "Voor de etymologie kan men het best van de vormen met $\hat{u}$ uitgaan. - 1. Genoemd naar het vraatzuchtige knagen van de rups, dan verband met roppen en roven. 2. Als het borstelige dier en dan volgens Kluge-Mitzka 587 te verbinden met rob 1. Maar lang niet alle rupsen zijn behaard." This statement includes the two most striking features of a caterpillar: on the one hand its ability to eat bare crops and trees, and on the other hand the hairy, bristly appearance of many (but not all) species of caterpillars. De Vries also mentions the two most obvious candidates for a formal connection of Dutch rups and German Raupe.

A reconsideration of the forms involved is undertaken in the following sections; in my view, the formal opposition between De Vries' comparanda Dutch roppen 'to rip', roven 'to rob' on the one hand and $r o b$ 'seal' on the other hand may be the result of Germanic developments from a single Indo-European root. As for the semantic motivation, it seems that 'the bristly animal' is the better candidate. Since much is still unclear about the different variants of the word for 'caterpillar' in Dutch, Frisian and German dialects, a thorough discussion of the evidence is justified.

2 The issue of rups and Raupo is addressed by Boutkan and Kossmann (1999), who discuss the different forms of the word for 'caterpillar' in Continental West Germanic (CWGm.). They point to the difficulties involved in the reconstruction of a single Proto-Germanic preform for all the variants; as a solution, they propose that the pattern of alternations attested for 'caterpillar' may point to the origin of this word in a nonIndo-European substratum language. In their view, the CWGm. words for 'caterpillar' share some of the characteristics of non-IE substratum

1 I would like to thank Robert Beekes, Jan Goossens, Frederik Kortlandt and Peter Schrijver for their comments on an earlier version of this paper. I am especially grateful to Joep Kruijsen, editor of the Limburgs Woordenboek at the University of Nijmegen, who has drawn the four dialect maps included in this article. 
words in Germanic, as they have been described and tentatively explained in a growing number by Kuiper 1995, Beekes 1996, Schrijver 1997 and Boutkan 1996 and 1998 among others. One such characteristic is the alternation between forms with a long vowel plus a single intervocalic stop, and a short vowel plus a geminate intervocalic stop, as per Kuiper 1995: 70f. and Boutkan 1996: 17f. An example of a set of forms with this alternation is ${ }^{*} k n \bar{u} b-:{ }^{*} k n u p p-:{ }^{*} k n u b b-:{ }^{*} k n a u p-$ 'round point, knob' (Kuiper loc.cit.)

Yet in the case of 'caterpillar', it seems to me that it is possible to derive the attested forms from one or more verbal formations which were present in Proto-Germanic, and which can be derived from a single Indo-European verbal root. This would imply that the problematic CWGm. forms for 'caterpillar' do not belong to the category of Germanic words borrowed from an unknown substratum language.

3 The form *rū $p(p)$ - 'caterpillar' is restricted to Continental West Germanic. It is unattested in the dialects of Britain, and in North Germanic. The only form which looks like a cognate is Faroese rupa 'red stone louse', which Young and Clever 1985 cite from the Dictionarium Faroense of Svabo, which I have been unable to consult. Since Far. rupa is an isolated attestation within Scandinavian, it must be left aside.

Within $\mathrm{CWGm}$., *rü $p(p)$ - is well-attested throughout the area, being absent only from the Bavarian dialects in the south-eastern corner. Those dialects use words like Krautwurm 'cole worm' or Graswurm to indicate the caterpillar, and such forms also occur in Swabian to the west of Bavaria (von Keller-Fischer 1920: 190). W- annot decide whether Bavarian once knew ${ }^{*} r u p p-{ }^{*} r \bar{p} p$-, and replaced it by other formations, or never possessed it in the first place. In view of the Old English forms for 'caterpillar' such as cawelwurm 'cole worm', leafwyrm and treowwyrm, the same can be said about the Anglo-Saxon dialects: they may have replaced a form * ${ }^{r} \bar{p} p(p)$ - by another formation, but they also may never have possessed it.

Which are the variants that occur in CWGm.? Boutkan and Kossmann 1999 reconstruct nine Proto-(West-)Germanic forms for 'caterpillar': *rūp-, *rīp-, *rupp-, *rūp-s-, *rups-, *rüps-, *rīps-, *ripsand, with hesitation, *rapp-. This implies a consonant alternation $p / p p /$ $p s$, a vowel alternation $i \bar{\nu} / u / \bar{u} /(a)$, and a large amount of contamination between these forms. Boutkan and Kossmann argue that the vacillating vocalism is a strong indication of the non-Indo-European origin of this etymon. I think that we can do with less original vowel variants: only $u$ and $\bar{u}$ are spread over a wide area, whereas forms in $-\bar{i}-,-e$ - and $-a$ - have a very limited distribution. They probably replaced $-u-$ or $-{ }^{*}-\bar{u}-$ under the influence of other stems in $r p$ which were close in meaning. The alternation between - $p$-, - $p p$ - and -ps- is caused by the different verb forms from which the word for 'caterpillar' was apparently derived.

4 We shall now describe the forms of 'caterpillar' in Germany, leaving the Dutch area for the next sections. The form * rappe is attested in several eastern German dialects. Grimm (1893: 298) mentions a form Rapp occurring in the Nürnberg area (e.g. in a 1482 vocabulary), but this must be due to contamination with German Rappe 'Pferdekrankheit, Flechtenart wobei die Haut rissig wird', Bavarian Rappen 'itch, mange, scab', Italian dialects rappa 'scabies'. With umlaut and High German consonant shift, we find Bavarian Räpfen 'scabies'. Germanic *rappo indicates a rough surface, and this causes the semantic overlap with the rough-skinned caterpillar, which gave rise to the formal contamination 2 . The $a$-vocalism is furthermore attested in a small area in Silesia (Mitzka 1964: 1092), and it was probably introduced elsewhere too; I found a form raba in the Thuringian dialect of Suhl (Spangenberg 1982: 68).

Apart from sporadic rappe, the forms * rūpo and * ruppō are the main forms on German territory. The whole of Frisian has * rūpo, which agrees with the northern Dutch area to the west and with the large Low German area to the east and south of Friesland. Already in Middle Low German, we find rupe (Schiller-Lübben 1877 III: 533), but no occurrences of ruppō. In the modern Low German dialects, rupe is still the only form attested, see e.g. Bretschneider u.f. (1994: 814) for Brandenburg or Wossidlo-Teuchert (1970: 1092) for Mecklenburg. The High German dialects further east also have *rūpo as their basic form: in Thuringia we find mostly rubə (Spangenberg 1982: 67), and in Prussian, rüp is the only form attested (Riemann etc. 1992: 756). The pronunciation with $[u]$ is important, because these dialects usually present diphthongized reflexes of $\mathrm{Gm} .{ }^{*} \bar{u}$ of the type Haus; the forms in $[u]$ suggest that 'caterpillar' was borrowed from Low German, after the diphthongization of * $u>a u$ had taken place (see below).

Further south, the map 'Raupe' in Müller 1948-58: 187-8 shows that

2 Michiel Driessen points out to me that another way to link 'scabies' with 'caterpillar' is through the fact that some caterpillar species are poisonous to humans, causing irritation to the skin and rash. A few years ago there was a plague of such a caterpillar, called processierups, in North-Brabant. 
the Ripuarian Rhineland has nearly exclusively the form ruppe for 'caterpillar', but a few relic forms of *rūpō are scattered around Krefeld. The uniform situation in Ripuarian is remarkable, because the form ruppe is only sporadically attested elsewhere. We can find it in several Swiss dialects, for instance in the Aargau and in Vorarlberg (cf. Staub etc. 1909: 1197), and in a handful of Thuringian dialects.

Moving from the northern Rhineland to the Palatian area south of the Eifel, we return to an area with reflexes of * rüpō. The border between ruppō in Ripuarian and * rūpō in Moselle Franconian closely resembles the course of other well-known isoglosses, such as the dorp/dorf-isogloss.

In all other High German dialects to the east (Hessian, Rhine Franconian) and to the south (Swabian, Alemannic), we find a form rupa or raup. The situation seems to be the same as in Thuringian and Prussian in the east. In dialects which did not diphthongize * $\bar{u}$, 'caterpillar' has merged with the reflex of PGm. $\bar{u}$, e.g. Alsatian rüp $<{ }^{*} r \bar{u} p \bar{o}$ (Martin etc. 1907: 277), and the form rūpe in several Swiss dialects (Staub etc. 1909: 1196). In some of the dialects where PGm. ${ }^{*} \bar{u}$ was diphthongized to ou or $a u,{ }^{*}$ rup a did not merge with PGm. * ${ }^{*}$. In the SE Swabian dialects near Augsburg described by Moser 1936, hous 'house' has the reflex $o u<{ }^{*} \bar{u}$; but the word for 'caterpillar' is ruapa (p. 86), -ua- being the reflex of Middle High German uo in those dialects. Von Keller-Fischer 1920: 190 explicitly states that rüpe is not the most common word for 'caterpillar' in Swabian.

This survey confirms Grimm's view (1893: 298), who assumed that the Middle and High German dialects with [rupə] or [raupə] $<*^{*}$ rūpo have borrowed this word from Low German. The main reason for this view is the preservation of intervocalic ${ }^{*}-p$-, which should yield $-f$ - in High German. No High German attestations before the 15th century seem to be known. Judging from the attestations gathered in Grimm, Raupe is used in the oldest texts especially for the harmful caterpillars, which can be a plague to crops. Possibly, the borrowing of Low German * rupa into High German was supported by the already existing word raup 'good-for-nothing, rough person, bully; yearling, heifer' (Grimm 1893: 298), attested in Tyrol, Bavaria and Swabia.

The (sporadic) High German attestations of ruppe are remarkable for their preservation of - $p p$-, as opposed to the regular affricate $-p f$ - in the verb rupfen $<*$ ruppon. There are two possible explanations. The first one is that we regard - $p p$ - as a case of expressive gemination in animal names, with a geminate which did not undergo the High German sound shift. Other examples of this phenomenon are quite numerous: German
Zecke to Dutch teek, German Zicke to German Ziege, German Bock to Dutch bok, cf. Wissmann 1975: 5. The second possibility is that Rup$p e$ in these High German dialects was made analogically to ruppen and ruppig. This seems the more attractive solution to me, in view of the scattered attestations.

5 We can now turn to the dialect geography of the Dutch linguistic area. The vocalism of the word $r p(s)$ - is indicated on map 13, which focuses on the southern half of the area. In the west and the centre of the Netherlands, the form of the standard language rups has ousted most of the older forms, and is therefore not indicated on the map. In the west, ${ }^{*} \bar{u}$ has become the diphthong $[\Lambda Y]$, and this form ruip is still widely attested in the north-west, in the area called West-Friesland ${ }^{4}$. Further to the south, it has presumably died out by now. The attestations of ruip on map 1 in the neighbourhood of Leiden and The Hague were given in the early 1970 s by speakers who recalled that their parents used this form, but they themselves used standard rups 5 . In the north-eastern provinces of Friesland, Groningen, Drenthe and Overijssel, which are contiguous to Low Germany, we nearly exclusively find the form [rupe]. This form too has not been indicated on the map, except for the seven most north-easterly attestations of $[\bar{u}]$ in the province of Gelderland, which show how far south the ruppe-area stretches

\footnotetext{
3 Maps 1 and 2 are based on the evidence from three different dialect enquiries known as the Enquête Willems (from 1885), the Enquête Schrijnen-van GinnekenVerbeeten (from 1914) and the Enquête Dialektcommissie (of 1971ff.), which I consulted at the Meertens Institute of Dialectology in Amsterdam. Maps 3 and 4 show the data for 'oprispen' contained in dialect enquiries nr. 10 and 10a, which were distributed in Limburg by the Department of Linguistics of Nijmegen University in 1961. The only other map of 'rups' which I know of is given by van Ginneken 1938: 112-113, who was interested in the development of the clusters $-s p$ - and $-p s$ His map does not provide the close net of vowel correspondences which we need for our present investigation.

4 For simplicity's sake, the symbol $[\Lambda Y]$ on Map 1 also subsumes the local vowel variants [oi], [ai] and [ $\varepsilon \mathrm{i}]$.

5 In Van de Water's 1904 description of a dialect of south-western Gelderland, just north of Den Bosch, I found the noun ruipenest 'nest full of caterpillars' (p. 126) preserving the old form *ruipe, whereas the usual word for 'caterpillar' was rups. This attestation is not indicated in the map. As can be seen, this ruipenest occurs further to the south than any of the Holland relic forms I took from the 1970s dialect enquiry. It is another indication that the $s$-less forms once prevailed everywhere north of the river Maas.
} 


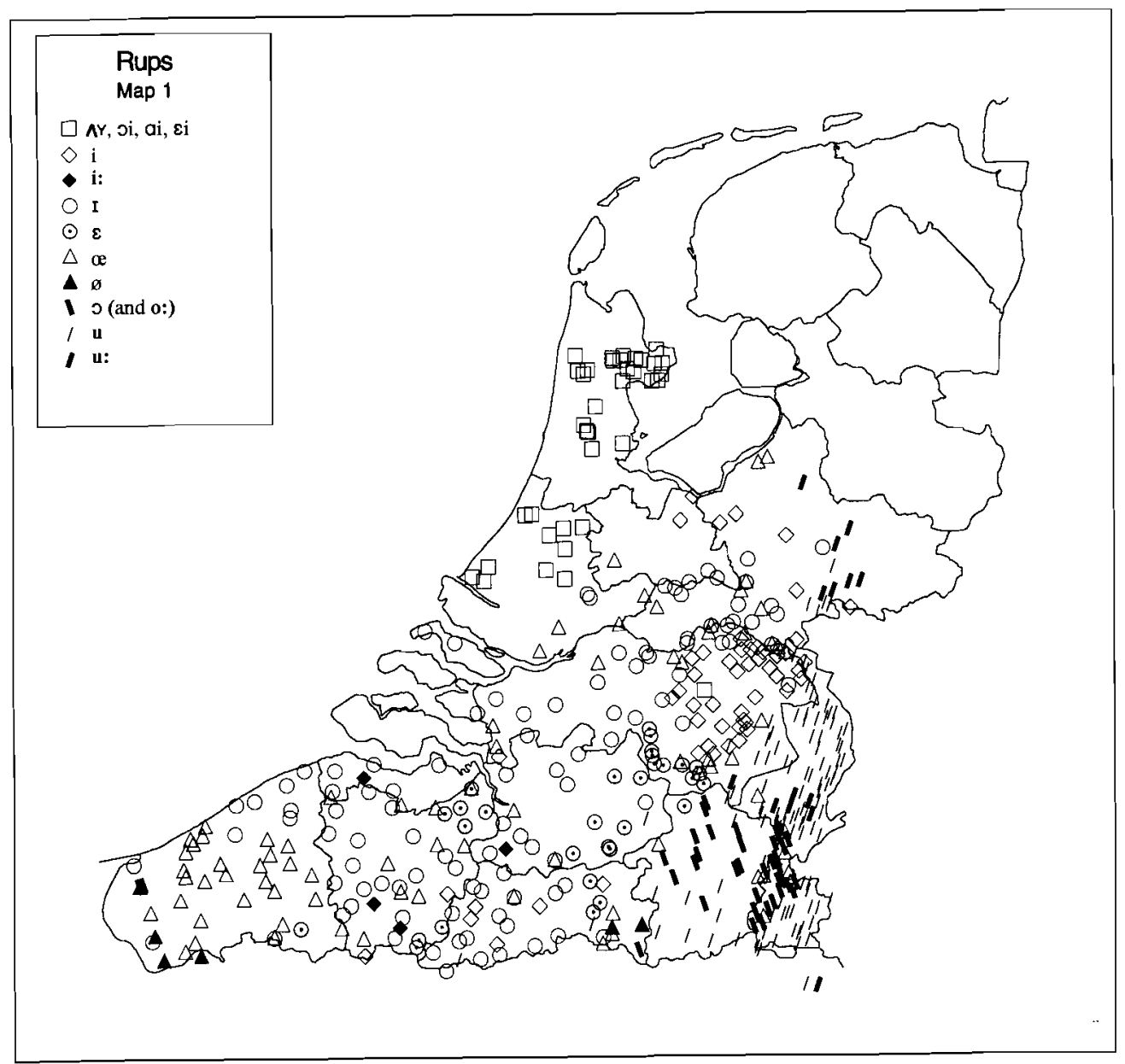

in the east of the Netherlands. North-eastern rüpe and the western relic form ruip allow the conclusion that the entire north of the Netherlands once used * rüpe.

All other vowel variants on map 1 involve an $-s-;$ usually they take the form $r$ ps $(e)$, but some of the deviant consonant types are drawn on map 2. We will start our survey in the south-east, where the situation is the clearest. For Limburg, Boutkan and Kossmann reconstruct * rüpsin order to explain the frequent reflex $[u]$ which they found in the dialect dictionaries; as they rightly point out, short $* u$ is usually reflected as $[o]$ in those dialects. Yet we can now see on map 1 that the centre of Limburg does have the reflex $[\supset]<* u$. If we compare the map of 'caterpillar' with other dialect maps of Limburg, the distribution of variants of 'caterpillar' matches other words in * $u$ quite closely6: northern and south-eastern Limburg have $[u]$ (with a few local lengthenings to $[\bar{u}]$ ), but central Limburg has lowered the vowel to $[o]$. The attested distribution cannot match ${ }^{*} \bar{u}$, especially in view of the reflex $[u]$ in northern Limburg, where ${ }^{*} \bar{u}$ yields $[\mathrm{Y}]$, and in the southeastern Brabant towns Deurne, Asten and Someren, where ${ }^{*} \bar{u}$ yields $[o j]$. It is remarkable that these latter towns go along with Limburg in this respect, since the dialect boundary between northern Brabant and Limburg is usually quite strict, and few innovations have passed it from the east.

The eastern part of North-Brabant, between the cities of Eindhoven, Den Bosch and Nijmegen, has the form [rips] (as if standard Dutch rieps). Prof. Goossens (by mail) has suggested to me the only possible reconstruction for this form in this dialect area, viz. WGm. *reops-< PGm. *reups-. As we shall see below, this different ablaut form of the root $* r u p(s)$ - fits in nicely with the rest of the evidence.

The pronunciation [roeps], indicated by the open triangles on map 1, prevails in West-Flanders and occurs sporadically everywhere in the South. In a few dialects in SW Flanders, $[\propto]$ was raised to $[\varnothing]$. Further to the North, especially in the central Netherlands, [ræps] as given in the dialect questionaries may simply be the standard form; but this is uncertain. The form goes back to $i$-umlaut of ${ }^{*} u$, i.e. ${ }^{*}$ rüps-. Its $* \ddot{u}$ cannot go back to the well-known western Dutch so-called 'spontaneous' fronting of rounded back vowels, since this fronting is usually restricted to a much smaller area, and especially the front vowels in

6 Compare the maps 'suiker', 'bok', 'hond'/mond' in De Vaan 1997 and the maps 'pop', 'bok', 'slok', 'lucht', 'krom' and 'pomp' in Goossens-Taeldeman-Verleyen 1998. 
Brabant occur too far east to be due to 'spontaneous' fronting7. A large part of the south of Gelderland. Brabant, Flanders and Zeeland is covered by the form [rips]. As Goossens points out to me, this area is too large and stretches too far east as to be explained by means of the well-known western Dutch unrounding of rounded front vowels. We must rather accept a preform * rips-, which must be ascribed to the mutual influence which the roots ${ }^{*} \operatorname{rup}(s)$ - and ${ }^{*}$ rip $(s)$ - exerted on each other (see below). For individual dialects in Flanders and Zeeland, it is possible that [rips] is the result of unrounding of * rüps-, especially since none of the Middle Dutch attestations from this area show $†$ ripse.

The form [reps] attested in southeastern Brabant bordering on Limburg, and more sporadically in East-Flanders, may locally be due to a lowering of *[rips], but it cannot be excluded that some dialects use a WGm. stem *reps-, different from *rup- and *rip-; see below.

The north-western Gelderland and Utrecht form [rips], viz. in Soest, Spakenburg, Voorthuizen and Hoenderloo, can only go back to $*_{i}$ since unrounding of $* \bar{u}$ does not usually take place in this area. The preform * rips is a local variant formation to southern Dutch *rips.

It seems less certain to me that the different $s$-less forms in northwestern Holland reflect WGm. ${ }^{*}$ rippo. Unrounding of $[Y]<{ }^{*} \bar{u}$ to $[i]$ is known from several different dialects in Holland, not only in WestFriesland, where this phenomenon can still be found 8 , but also e.g. in Egmond aan Zee, in Wateringen, and on the island of Vlieland. Weijnen 1966: 226 suspects that this unrounding was once more widespread than it is now. Therefore, the Texel form riep may also be due to unrounding. I was unable to find the Frisian form riep, which Boutkan-Kossmann cite from page III,47 in Dijkstra's dictionary (18981911); the only form I find there is the expected rûp.

The strongest evidence for * ripo would seem to be the 17th century $s$-less form rijp 'rups' $\left(</{ }^{*} r i p /\right)$, which is used sporadically by various authors such as Bredero, Cats, Luyken and Vondel. They use rijp as a variant of the then already standard form rups(e). For instance, Cats has the sentence Op het afdoen van rijpen of rupsen in de boomen. The form rijp seems to have been a dialect variant which these authors used for stylistic reasons. It apparently never rose from its sub-standard

${ }^{7}$ Compare for instance the dialect reflexes of * $u$ in the maps 'pop', 'bok', 'wol' and 'zon' in Goossens-Taeldeman-Verleyen 1998.

8 The forms rijp, rijpe in Zaanland, Drechterland and Monnikendam can be regarded as unrounded diphthongs ${ }^{*} o i<{ }^{*} u i$, and they are included under the symbol $[\Lambda \mathrm{Y}]$ on map 1 . status, so that it disappeared again and we now find only rups and ruip in the Holland dialects. Because of the earlier attestation of rijp, it is less certain that it can be due to unrounding of $* \bar{u}$.

In conclusion, the preceding survey has shown that the original form was * rūpe in Holland, Friesland and the northern and eastern Saxon dialects, with a few occurrences of *ripse and possibly also ${ }^{*}$ ripe. Limburg in the south-east has *rupse, eastern North-Brabant *reupse, and the remaining southern dialects of Brabant, Flanders and Zeeland have *rüpse, *ripse and *repse.

6 The dialect geographical data are largely confirmed by the forms for 'caterpillar' found in Middle Dutch. The lexicon of Teuthonista (before 1477) has only the forms rupe, ruyppe vel sim. < rūpo. Kiliaan (1599), who collected forms from all over the Dutch area for his lexicon, has ruype, ruepe, roepe (in Friesland, Holland and Overijssel) beside the southern forms rupse, rupsene (from East Flanders), and the form ruepsene /rypsene/, which I have not found in a single dialect. In accordance with the indications that the form ruip $(e)$ once held sway in all of Holland, the Delft Bible has a preference for rupe; the Hague Bible also has ruupse/rypse/, which I only met in the dialect of Hoogerheide, $20 \mathrm{~km}$ to the north of Antwerp. Even Van Maerlant, who wrote at the end of the 13th century in Flemish, employs northern rupen 'caterpillars' beside Flemish rupseme, rupsene. We can safely say that the form rupse and its descendants have gained teritory over the centuries at the cost of the form *rupe.

7 Surveying the entire Continental West-Germanic evidence, we can say that the form * rūpo is original in all dialects except for Low Franconian ${ }^{* *}$ rupso $/ * *$ reupsö/** rüpso/** ripsō/**repsō, a Rhenish area which has ${ }^{*}$ ruppó but with dispersed relics of ${ }^{*} r u \bar{p} \bar{o}$, and sporadic occurrences of * ruppō in Switzerland and Thuringia. We shall discuss the possible origin of each of the three main variants.

As *rüpö 'caterpillar' is isolated within CWGm., having no other verb or noun of the structure rup-beside it after which it could have been formed, and since * rūpo has the most widespread attestation in Low German and Dutch, I assume that *ruppo is the original CWGm. form. It may originally have been restricted to the dialects of Low CWGm., whence it was borrowed into High German at a later stage. As I will explain in section 12 below, * ${ }^{*}$ ūpo can be derived from the Gm. root Vrup-/rupp-/rub- 'to be/make rough'. 
The form * ruppo is restricted to one larger area where it is the majority form, but where remnants of * rūpó are also found; it occurs sporadically elsewhere in Germany and Switzerland. The introduction of rupp-can easily be explained from analogy with the verb * ruppon and the adjective ruppig 'rough, shaggy', which are also attested all over CWGm

8 The $s$-forms *rups- and *rüps- are explained by Boutkan and Kossmann 1999 from original $s$-stem variants, e.g. "* rūp-o neben * rūp-s$\bar{o}$." This seems unlikely because it would imply that West Germanic had preserved an $s$-stem * rūp-es-, which is unattested, and a derivative

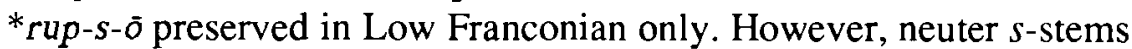
are a disappearing category already in Old Germanic. The form * rupes- would have been the PIE preform, but there is no trace of it 9 . It seems more promising to look for an origin within Low Franconian 10.

The best candidate for the role of trigger for the replacement of * rüpo by *rupsō 'caterpillar' in Low Franconian is the CWGm. verb * rups(j)an 'to make a coarse, rippled sound', as reflected in German rüpsen or röpsen (Grimm 1893: 1535), modern German rülpsen 'to clear one's throat; to burp'. Many aspects of the southern Dutch dialect forms of 'caterpillar' can only be explained in a satisfactory way if we assume that 'caterpillar' is derived from 'to belch'. The connection between 'to belch' and 'caterpillar' may be the way in which a caterpillar moves forward, viz. by slowly pushing itself foward, first with its hind legs, thus raising the central part of its body to a curve, which is lowered again when the front legs move forward. This movement may easily call into mind the lowering and raising of the Adam's apple when people belch, or retching movements of the throat when vomiting11. As

9 The word for 'wasp', which also has *-ps-, was not an $s$-stem in PIE: Gm. *wapsō combines with Lith. vapsà, Russ. osá, Lat. vespa etc. as PIE *uob ${ }^{h_{s e h}}$.

10 Another possibility would be to derive *rupso from the addition of a suffix PGm. *-sa- to an animal name, a derivation type which was possible in PGm. (Brugmann 1904: 331). A well-known example is MoHG Fuchs, MoE fox < *puk$s$ - $a$-'fox', which can be contrasted with Goth. fauho, OHG foha, OIc. fóa * *fuhon'female fox' < * puk-. In PGm., this procedure was used especially to distinguish between male and female animals. Two arguments impair this hypothesis: rupse is a feminine, and its distribution seems too limited within CWGm. to make such an old origin probable.

11 I owe this semantic motivation to my colleague Rieks Smeets, to whom it occurred when I told him of my idea to connect rups and oprispen. the proposed connection will seem unusual to most readers, I will present the evidence for it in the following two sections: in section 9, the vocalism of 'to belch' will be discussed, and in section 10 , the verbal suffixes.

9 The opposition between a Limburg form * rupse as against * rüpse in the area to the west of Limburg is mirrored by the distribution of the forms *rupsen and *rüpsen for 'to belch'. In Ripuarian, the umlauted form röpschen dominates the Rhineland west of the Rhine from the Eifel to Heinsberg, Erkelenz and Mönchengladbach (Müller 1948-58: 505); yet further to the south in Germany, the vowel $-u$ - must originally have been used, since we find rupschen in Neuwied near Koblenz (Müller), and once rubse in southern Hessen (Maurer 1978-85). By now, most German dialect forms in central Germany have given way to standard rülpsen.

Unpalatalized forms are also attested in Middle Dutch ropsenen 'ructare' and ropsenlec 'ructim', viz. in the Vocabularius Copiosus, which according to Van Sterkenburg 1973: 36 is a mixture of southern Brabant and Limburg language; compare furthermore Early MoD rospelen 'to belch' in Plantijn. This raises the question whether we can find unpalatalized forms *rupsen in the present-day dialects of Limburg, and in order to find the answer we must turn to map 3 . This map indicates the vocalism of 'to belch' in Limburg and in a few adjacent Brabant dialects.

Nearly the whole of Dutch Limburg south of Venlo has the form [ræpsa] vel sim. < *rüpse, thus joining the Ripuarian dialects to the east ${ }^{12}$. Whereas the attestations of $[\propto]$ form a close net in Dutch Limburg, they make a sudden halt at the Dutch-Belgian border; as this border dates from 1839, the palatalized vocalism must have undergone a recent expansion from a smaller source area within Dutch Limburg13. Only six dialects are reported to have an unfronted vowel $[u]$ or $[0]$; in view of their seemingly random distribution, the recent advance of $[\propto]$, and the Middle Dutch attestations of ropsenen and ropselen, the unfronted vowels may be interpreted as relic forms. This view is

12 I assume that the four entries of [rex:psa] (spelled as rèùpse) are due to local lengthening of $[\propto]$.

${ }^{13}$ This explanation is to be preferred to the theoretical possibility that $[x]$ was ousted by other forms in Belgian Limburg. The forms for 'to belch' are everything but uniform in Belgian Limburg, which means that there is not one variant which was or is ousling verbs with a different vocalism. 


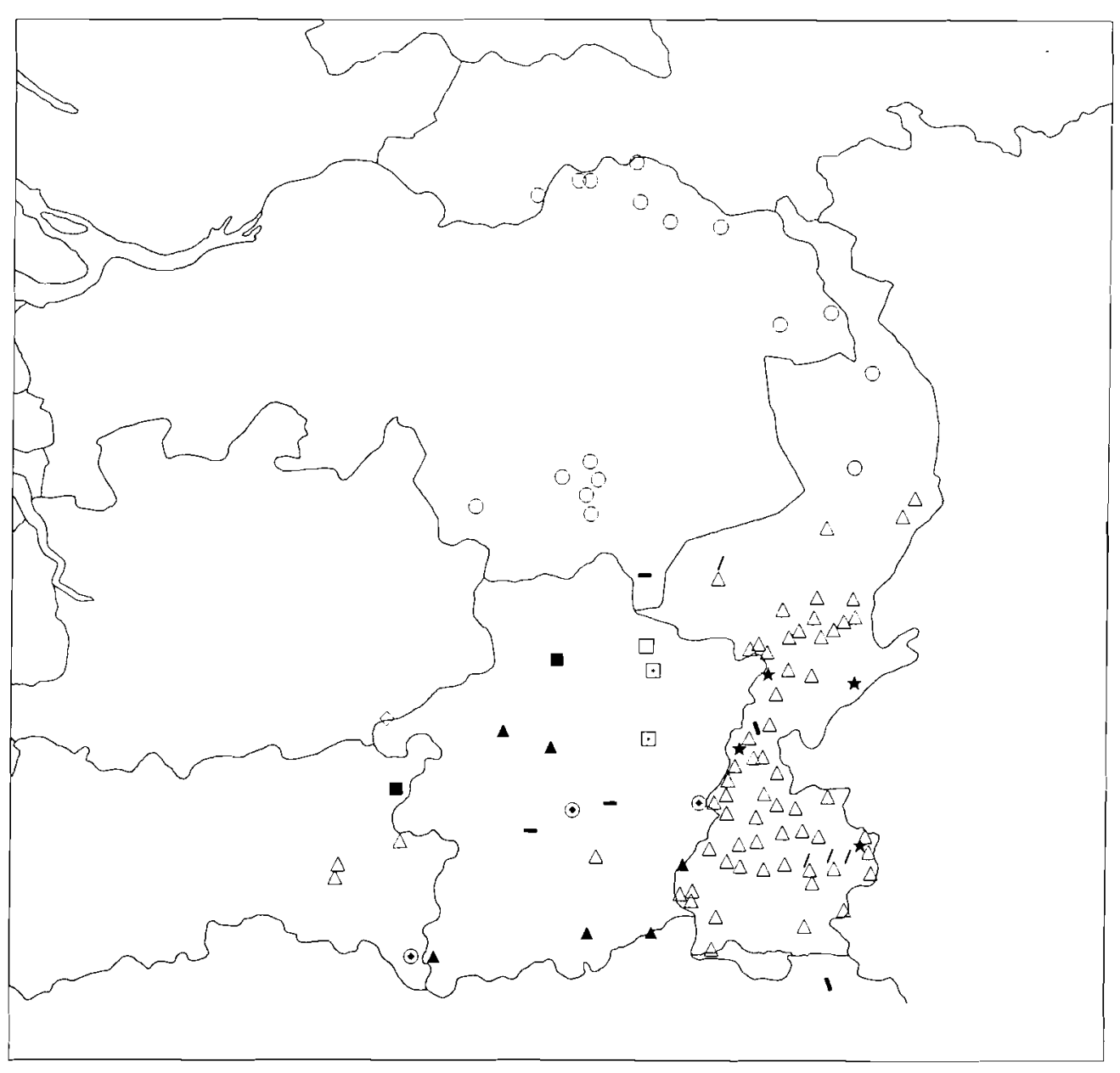

\begin{tabular}{|c|c|}
\hline & $\begin{array}{l}\text { Oprispen } \\
\text { Map } 3\end{array}$ \\
\hline$\square$ & Ar \\
\hline$\odot$ & દi \\
\hline 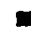 & Y \\
\hline$\partial$ & i \\
\hline 0 & 1 \\
\hline$\odot$ & $\varepsilon$ \\
\hline- & e: \\
\hline$\Delta$ & $\rightsquigarrow$ \\
\hline$\star$ & œ: \\
\hline$\Delta$ & $\propto(:)$ \\
\hline 1 & 0 \\
\hline 1 & $\mathbf{u}$ \\
\hline
\end{tabular}

strengthened by two cases where we can compare different information for the same dialect. For Maastricht, Endepols 1955: 352 gives an unrounded form ropse, whereas the 1961 Nijmegen enquiry yields $[\varkappa]$. This same enquiry has recorded [o] for Moresnet (in the southeastern corner of the map), whereas the nearby town of Montzen had röpse already in Welter 1933: 9 .

In Belgian Limburg, a preform * räupselen can account for most of the attested pronunciations. In the north and south of the province, ${ }^{*} \ddot{a} u$ has yielded a vowel $[\phi(:)]$ or a diphthong $[\Lambda Y]$, which are unrounded in the central Belgian Limburg unrounding area, represented on the map by Hasselt and Genk 14 reepsele and Opglabbeek and Bree reipsele. Bokrijk repsele is probably due to a local shortening of reepsele 15 . The two $[Y]$ forms in Eksel and Diest can also go back to *räupselen. This preform has exactly the same vocalism as the form räupschen 'to belch' given by Müller 1948-58: 191 for the Central Franconian dialects around Trier and Koblenz.

Three places in the southeast of Flemish Brabant have [rospele], with the same vowel as in Dutch Limburg. Only one place in Belgian Limburg (Beverst) shows this $[\propto]$, and furthermore Stevens 1986: 492 gives [ropsele] for Tongeren. Since map 3 shows the vowel $[\varnothing:]<* a ̈ u$ for Tongeren, it is possible to regard the form given by Stevens as a local shortening of $[\varnothing:]$; but we must also reckon with the possibility that the different variants * rüpselen and *räupselen have existed or still exist side by side in some dialects.

The eastern North-Brabant and northern Limburg area with [1] forms the southeastern end of a large area with short $*_{i} 16$, which is also the vowel of the standard Dutch word op-rispen (with metathesis of *ps). I

14 The Nijmegen enquiry has ripsele but Goossens, native from Genk, informs me that his form is reepsele and that ripsele is unknown to him. Ripsele must be a local or even personal shortening of reepsele.

15 But the same form repsele in Smeermaas, near the border, cannot derive from * räupselen since this dialect does not usually unround rounded front vowels. Possibly, older * räupselen, * rüpselen or * rupselen was replaced by *repselen, a form which I found reflected in the unique southeastern Brabant form [repsolo] 'to ruminate' which the WBD p. 406 gives for the town of Landen. The meanings of 'to belch' and 'to ruminate' are very similar, and as Goossens suggests to me, the informant for Landen may have confused the words 'to belch' and 'to ruminate'. For this reason, Landen $[\varepsilon]$ has been included on the map.

16 This includes the Budel attestation with $[e]$ opreespen, since this dialect often lowers $*_{i}$ in a closed syllable, especially in front of $s$; cf. van de Wouw 1968: $167 f$. 

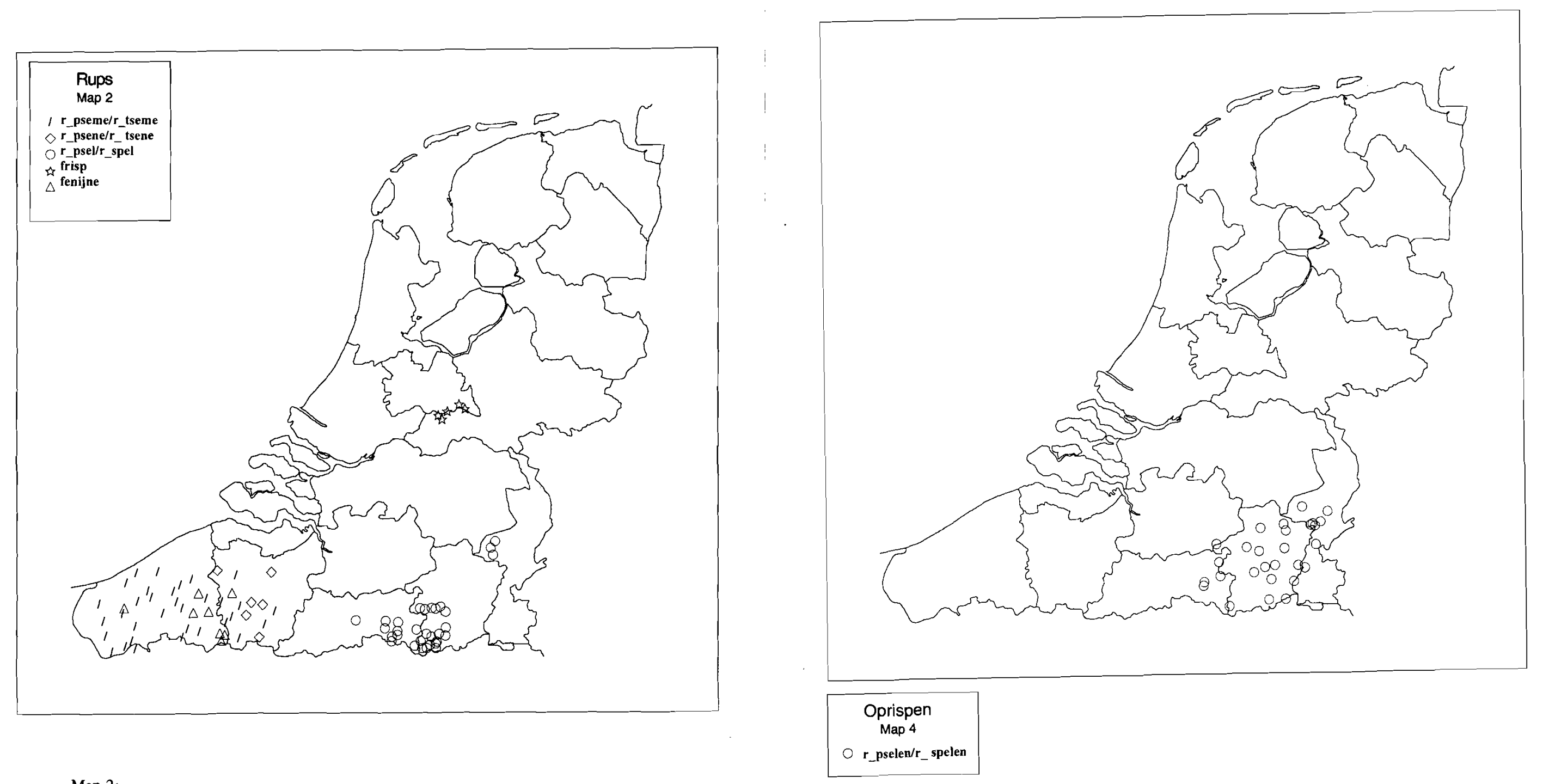

Map 2:

The types $r$ pseme, $r$ psene and $r$ psel are probably built on the frequentative verb forms for 'to belch'. The type fenijne is a loan from French. The type frisp must be due to the influence of other Dutch words in $f r$ - which indicate something curly or folded, such as frons 'wrinkle', frommelen 'to fiddle, fumble, frutsel 'trinket', freissem (WNT) 'kind of rash'. 
have extracted the Brabant data from the files of the lemma 'to belch' which will appear in the $W B D 17$, but in most places, this verb was not glossed by the etymon ripsen/rupsen but by a different verb, so that Brabant is poorly represented on the map. Van Ginneken's map (1938: 112 ) of 'oprispen' in Dutch shows a vowel variant $[\varepsilon]$ in various smaller areas; this may partly be due to local lowering of * $[1]$ in front of $-s p-18$, but in general we may assume the occasional intrusion of a genuine WGm. ${ }^{*} e$, which was taken from another verb in the same semantic sphere, probably OHG hrespan 'to pluck', MHG respen 'to snatch'. The vowel $[\varepsilon]$ in 'to belch' is much more frequent in Ripuarian and in Central Franconian, where Müller 1948-58: 100f. cites räpsen and räpschen from numerous towns, and even the noun Räpsch 'das Aufstossen' from Heinsberg, close to the Limburg border. These facts confirm the $-i$ - and $-e$ - spellings found for 'to belch' in late Middle and early Modern Dutch. Kiliaan has ripsen beside rupsen 'to burp, vomit', and Teuthonista oprepsen and oprispelen. We may conclude that, as in the case of 'caterpillar', the root *rups- was replaced by the formally and semantically closely similar verbs *rips- and *reps- in an unpredictable, seemingly haphazard way. In fact, this replacement can be witnessed in earlier sources and on a larger scale for 'to belch' than for 'caterpillar'.

10 The connection of Low Franconian 'caterpillar' with 'to belch' may be further supported by the different verbal suffixes which appear with 'to belch'. The lexicon of Kiliaan presents a form rupsemen 'to burp, vomit'; as map 2 shows, rupseme for 'caterpillar' is attested only in Flanders. This suggests that the verb was already rupsemen in Flanders when the name of the 'caterpillar' was derived from it; this suggestion is strengthened by the fact that -emen is much easier to understand as a frequentative verbal suffix than as a noun formative. The same can be said about the other variants indicated on map 2: the verbal suffix -enen appears in Voc.Cop. ropsenen and ropsenlec (cf. above), and -elen is attested in MHG riuspeln etc., in Early MoD rospelen, and in the modern dialects of Belgian Limburg and a few towns in Dutch Limburg, as shown by map 4 . The suffix -elen in Limburg largely covers the same area as in - $e l$ in 'caterpillar' on map 2, thus supporting the

\footnotetext{
17 I kindly thank Joep Kruijsen for providing these data to me.

18 As seems probable for the Waasland region in the north of East-Flanders, which is the largest area shown with $[\varepsilon]$ in van Ginneken's map. The Waasland is also one of the areas with a concentration of $[\varepsilon]$-forms in 'caterpillar', see map 1 .
}

hypothesis that $-\mathrm{el}$ in 'caterpillar' follows the example of -elen in the verb 'to belch'.

11 Let me summarize the result of the two preceding sections. The CWGm. forms for 'to belch' display an alternation between different ablaut variants of the root *rups- (*rups-/*rüps-, *riups-, *raups/*äups-) in interchange with *rips- $\left({ }^{*}\right.$ rips-, *raips- $)$ and *reps-. The Low Franconian forms $* r$ ps- 'caterpillar' show the same alternation of ablaut variants (*rups-, *rüps-, *reups-; *rips-; *reps-) and suffixes (emen,-enen,-elen), with a geographical spread that is sufficiently similar to that of 'to belch' to justify the conclusion that 'caterpillar' has been formed from the same basis as 'to belch', and not once but many times anew in the individual dialects.

The interchange of the Germanic roots *rup- and *rip- has been mentioned several times in earlier literature on Dutch dialectology. One example seems especially interesting for the present problem. Goossens (1963: 41 and 86) has discussed the reflexes of Gm. *raupian 'to pluck' in the south of Belgian Limburg, where this verb is preserved with the meaning 'to pull out rapes for cattle-fodder'. Whereas the eastern part of Belgian Limburg has [rø:pa] or [re:pa] < *äupen, the area to the west has $[$ reip $]<*$ raipen. Goossens concludes that, as in many other cases, the roots raup-/rup- and raip-/rip- have influenced each other from an early moment on 19 .

The vacillation in the root vowel and ablaut of 'to belch' is due to the association of this verb with other verbs of a comparable form and meaning; we have seen for instance that Dutch respen may be ascribed to the influence of CWGm. *hrespan 'to pluck, snatch'. Another example is provided by the Belgian Limburg form reconstructed as *räupselen, and Central Franconian räupschen 'to belch' (see section 9), which must have adopted the root form * räup- < Gm. *raupjan 'to tear' (Goth. raupjan). Once we recognize these replacements, the vowel alternations displayed by 'to belch' and by 'caterpillar' lose their apparent irregularity and arbitrariness, which has often prompted investigators to brandish words exhibiting such alternations as 'affective' or 'expressive' words. What characterizes them is the fact that they, more

19 It follows that unexpected vowel alternations do not prove the influence of a non-Germanic linguistic substrate (or superstrate) language. Granted the presence of the roots *rup- and *rip- in Proto-Germanic, which is beyond doubt, the later dialects could make good and innovating use of the possibilities offered to them by ablaut. 
often than other words, undergo analogical change due to the influence of words with which they are associated in meaning; but they are in no way exceptions to the acknowledged processes of linguistic change.

12 As was indicated in section 1 , the two most likely original meanings of *rūpó are either 'the gnawing one' or 'the bristly one'. It seems to me that the word field in which 'caterpillar' occurs decidedly points to the second possibility. In the first place, we have the MLG gloss rupe is ene rughe made (Schiller-Lübben 1877 III: 533) 'caterpillar means a rough maggot'. In Frisian, the noun rupert means a 'rough-haired animal'. A similar definition of Dutch rupse is given by Kiliaan: "millepeda, centipeda, hirsuta: vermis terrae pilosus, [...] ex erucarum genere," 'millepede, centipede, bristly: hairy worm of the earth, [...] from the species of caterpillars'. In the second place, the occasional contamination with Rappe 'mange, scabies' for 'caterpillar' in High German must be motivated by the bristly skin of (some of the) caterpillars. In the third place, several other CWGm. forms in *rupp- are attested with a meaning 'bristly'. According to Grimm, Ruppe indicates a 'fish with a thick head', but also a pimple in the face. In Swiss dialects Staub e.a. (1909: 1197) report rupp 'rough-haired, crisp-haired', and Rupp 'the worst part of the hamp which remains after hackling'. It is clear that all these forms have the coarseness of a surface or an unevenness in a smooth surface as a common feature. The adjective ruppig 'shabby, rude' originates from north and central Germany, and is probably derived from the verb rupfen, OHG ropfon, Low German ruppen, Dutch roppen 'to pluck, to fleece', which is said of plucking a bird's feathers, or of wool working. This verb is attested in all CWGm. dialects, and in High German it has undergone the consonant shift.

Even if we admit that not all caterpillar species have a rough skin, certainly the ones regarded as the most characteristic ones have an indented silhouette and a hairy(-looking) skin. We can find parallels for the hairy skin as a characteristic of the 'caterpillar' in its name employed in other languages. French chenille derives from Latin canicula 'little dog', and De Bo 1873: 359 mentions a form harenhond 'hairy dog' for West Flemish. In Romance, the word for 'cat' has often been used to refer to the caterpillar. A compound *catta pilosa 'hairy cat' lies at the basis of many French dialect forms for 'caterpillar', cf. von Wartburg 1940: 521, who mentions 14th century French chatepelose, Corsican gatepiloze and the borrowed form chasplouzen in the Breton dialect of Vannes. English caterpillar reflects borrowing of the same
Old French etymon, and it has probably been adapted in its second member to piller 'to sack'. In Piemontese dialects in northern Italy, the word gata is used for 'caterpillar', and in combination with the word for 'beast', Veronese dialects have bissa gata 'cat-beast' and bissa pelosa 'hairy beast' (Beccaria 1995: 17). Albanian gucimacë 'caterpillar; larva, maggot, grub' is built from the words gucë 'puppy' and macë 'cat'. Within the Germanic area, we find the form wëll Kaz 'wild cat' used for 'caterpillar' in Luxemburg (Klees 1981: 23), and Tüfelschatz 'devil's cat' in Switzerland (Staub etc. 1909: 1196).

13 As I have argued in section 7, I believe that * rūpō was the original word for 'caterpillar' in (Low) CWGm. The preceding section 12 has yielded the conclusion that the original meaning of ${ }^{*}$ ruppo $\overline{\text {, in other }}$ words the naming motive for the caterpillar, was 'the bristly one'. It is now time to discuss the Proto-Germanic origin of * rüpo. Section 13 disclaims the proposed connection with a root *rVp- 'to creep', and section 14 will defend the derivation from PGm. *rup- 'to break'.

As we have seen in section 1, rups and Raupe have mainly been connected with two different groups of forms. The comparison with Dutch roppen, German rupfen and Gothic raupjan has the advantage of being impeccable on the formal side; but it is often felt that the meaning 'to pluck' is difficult to match with a caterpillar's activities, which is why this connection is often rejected. The comparison of rups etc. with Dutch rob, German Robbe 'seal', MiDu robbe 'rabbit', an animal with whiskers, can easily be reconciled with calling a caterpillar 'bristly'; but here, intervocalic *-bb-flaws the direct comparison.

As an alternative etymology, Boutkan and Kossmann propose to connect *rup- 'caterpillar' with a root * $r V p-20$ 'to creep', attested in Lat. repo 'to creep, crawl', and in Lithuanian réplióti, roplóti 'to creep', Latvian râpât, râpt 'to creep', to which Old Prussian ripaiti 'folget', serripimai 'erfahren' may belong. Some Germanic forms are also usually connected with Lat. *répō, viz. OIc. ráfa, OHG reba 'vine' etc., but Boutkan and Kossmann judge the connection of the Germanic forms doubtful. They show that the limited distribution (Latin, Baltic,

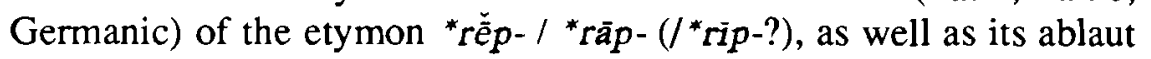
pattern, make the assumption of PIE origin difficult to defend, and they accordingly propose to regard this root as a substratum word.

Whereas it seems quite plausible that OIc. ráfa, OHG reba etc. must be assigned to a substratum layer, it seems unlikely that this substratum

20 In which $V$ may be any vowel. 
root *rVp- 'to creep' also furnished the CWGm. forms for 'caterpillar'. We have seen in the previous sections that the vocalism of 'caterpillar' is not as chaotic as it might seem at first glance, and that we can basically reconstruct $*_{r \bar{u}} \bar{o}$ as the oldest form, which alternated with ${ }^{*}$ ruppō or was in some dialects replaced by it. If CWGm. ${ }^{*} r u \bar{p} p(p)$ would be connected with Latin répo etc., it is strange that the root vowel - $\check{\bar{u}}$ - does not appear in any of the Latin or Baltic forms, nor in the possibly cognate Germanic forms of * rềp- 'to creep'. Furthermore, since *-p- in * rupo cannot correspond with Latin or Baltic - $p$-, Boutkan and Kossmann (1999: 9) assume that *rupo 'caterpillar' entered Proto(West-)Germanic after the first consonant shift, which shifted ${ }^{*} p$ to ${ }^{*}$. This would mean that German Rebe etc. cannot be derived from the substrate root ${ }^{*} r V p$ - 'to creep' because it shows the result of Verner's law; yet as to meaning and form, Rebe and OIc. ráfa are much easier to connect with Latin rêpo than are the words for 'caterpillar'.

14 The meaning of $*_{r u} \overline{p o}$ decidedly points to the older connection with Got. raupjan, OS rópian, OE riepan, OHG roufen 'to pick, fleece'. The semantic background of this connection has been explained in section 12 . We have seen that the variant ${ }^{*}$ ruppo must be due to the verb * ruppōn, which belongs to the same root as Got. raupjan etc. Similarly, Low Franconian *rupsōo* rüpsō, etc. was formed on the basis of a verb *rups $(j)$ an 'to belch', which belongs to the same Germanic root * rup-21. This root has yielded many different forms in Germanic, with an interchange between the consonants $-p-,-p p-,-f$ - and $-b b$-, and between the alternating vowels $* u, * a u$ and $* \bar{u}$. At first sight, this interchange seems too haphazard to be explained from inherited stock, but the meaning does not allow us to separate the different forms, and a satisfactory formal explanation can in fact be given.

Our starting point is the PIE root *rup- 'to break', as in Skt. rúpyati 'to have pain in the stomach' and Latin rumpo, rūpi 'to break'. This root is attested with the meaning 'rough' in Baltic: Lith. rupti 'to become rough', rupùs 'rough', ruplé 'the rough bark on old trees', raupsaî 'rash', raũpti 'to scratch open', raũpas 'pock'. In the animal name rupūžè, rupuzue, raupežé 'toad', it refers to its rough skin, which

21 The verb *rups(j)an specialized to the meaning 'to belch' in the same way that German acquired sich erbrechen 'to vomit'. Other Germanic derivatives of * rup- with the same meaning are e.g. OIc. rypta 'to vomit' and OHG roffezzen, ropfezzen< *rupatjan (De Vries 1971: 494), OIc. ropa 'to belch', OSwe. drypja<*-rupjan 'to ruminate', and MLG upropen 'to belch' < *-raupon. provides a nice parallel for the derivation of 'caterpillar' in CWGm.

In Germanic, *rup- yielded many different forms, which can basically be explained on the basis of Lühr's scenario (1988: 369 , see also $351 f$.). The voiceless fricative $-f$ - appears in OIc. rauf 'broke', reyfa 'to pierce', and in the intensive *ruff-al-on with gemination in front of $-l$ - (MoDutch roffelen 'to roll the drums', EFri. ruffelen, German rüffeln 'to blow up', MoE to ruffle). The verb PGm. *ruppōn 'to tear', attested in OIc. ruppa, MoE to rip, NHG rupfen represents the intensive formation *rup-no. The geminate -pp-is best explained with Kortlandt's chronology (1991: 2f.): 1. Verner's Law *rup-nó- > *rubnó-, 2. Kluge's Law *rubnó- $>$ *rubbo-, 3. Grimm's Law $*_{\text {rubbo-- }} *^{*}$ ruppō-. Intervocalic - $p$ - in Goth. raupjan 'to tear', OHG roufen 'to pluck' probably represents the original causative PIE *roupéie- (> PGm. †raubjan), which adopted -pp-from the intensive * ruppōn (thus Lühr 1988: 352), and simplified the geminate *pp after *au (cf. Prokosch 1939: 70). This verb then provided the intervocalic *-p- which we find in *ruppo- 'caterpillar'; whether or not this went via an unattested verb ${ }^{*}$ rūpōn is impossible to tell. Long *- $\bar{u}$ - must have a so-called secondary full grade, like in the class II strong verbs such as *sūpan, *Iūkan; we also find this *ü in North Germanic in OIc. rúfinn 'rough-haired', ODan. $r u(<* r u v-)$, Dan. dialects $r u$ 'wrinkle, pleat', Norse dialects ruvla 'wrinkle, furrow'; in Dutch dialects we find ruiven 'to moult'. The latter forms go back to * $r u \bar{b}$ - (Falk-Torp II: 915f.), which has retained $-b$. The intensive *rubbon has specialized in the meaning 'to scratch': MoE to rub, EFri. rubben 'to scratch', Norse, Dan. rubbe, Swe. rubba; this formation must be based on the preform * rubbo-which arose as a result of Kluge's Law.

Just like * ripsō is due to a recent mirrorring of an $u$-vowel root *rups-by an $i$-vowel root *rips- (see above), in the same way the Dutch forms which seem to continue *ipo- may be derived from WGm. *ripan 'to tear', attested e.g. in OE ripan 'to reap', OS *ripi 'ripe', and with short $* i$ in OIc. rippa 'to tear' and MLG repen 'to break flax' < *rip-. This was already suggested by De Vries apud van Haeringen 1936: 141, and further elaborated by Berns 1974, especially p. 186, who has included all Dutch $-f$ - and $-v$ - variants. The Germanic forms can be connected with Greek ereipo 'to throw down, tear down', ereipios ge 'river bank', and Latin ripa 'river bank' (Lühr 1988: 352$)$. As the roots * rup- and * rip- show very similar consonantvowel alternations, and since they share the meaning 'to tear, to break off abruptly', it is conceivable that these roots, or at least part of their derivatives, were near-synonyms until fairly recently in the history of 


\section{Germanic.}

15 I have argued that we need to regard only * rūpō as a certain CWGm. form for 'caterpillar'. This form was lost in Low Franconian in favour of the forms * rupsō and *rüpsō, while it yielded to * ruppō in the northern Rhineland and sporadically in other German dialects. The motivation for this replacement was the existence of verbs and adjectives with a form similar to "rūpo which at the same time had a meaning 'to be/make rough', which provided a good semantic motivation for the derivation of a word for 'caterpillar'. The nouns * rupsō and "ruppō may of course have already existed in PGm. side by side with * rūpo, but this does not seem likely in view of their limited distribution.

All this implies that we can regard Dutch rups and German Raupe as Indo-European heritage. The hypothesis that 'caterpillar' represents a substratum word from an unidentified language, a hypothesis which was motivated by the different variants observed in the present-day dialects, must be rejected. We therefore conclude with the warning that the - justified - increasing attention to substratum features in Germanic must not feed on an increasing scepsis about Indo-European explanations.

\section{REFERENCES:}

Beccaria, G.L. 1995: I nomi del mondo. Santi, demoni, folletti e le parole perdute, Torino.

Beekes, R. 1996: Ancient European loanwords, Historische Sprachforschung 109, 215-236.

Berns, J. 1974: Artikel 'ruif', in Toelichting bij de Taalatlas van Noord-en ZuidNederland II, p. 170-222.

de Bo, L.-L. 1873: Westvlaamsch Idioticon, Gent.

de Bont, A.P. 1962: Dialekt van Kempenland, meer in het bijzonder d'Oerse taol, Assen.

Boutkan, D. 1996: Riustring fal, fili and sincfalon, $U s$ Wurk 45, 1-21.

-. 1998: On the form of North European substratum words in Germanic, Historische Sprachforschung 111/1, 102-133.

- and M. Kossmann. 1996: Het stadsdialekt van Tilburg, Amsterdam.

-. 1999: Etymologische Betrachtungen zur Dialektgeographie von Raupe, rups', Amsterdamer Beiträge zur älteren Germanistik 50, 5-11.

Bretschneider, A. u.f. 1994: Brandenburg-Berlinisches Wörterbuch, dritter Band, Leipzig.

Brugmann, K. 1904: Kurze vergleichende Grammatik der indogermanischen Sprachen, Strassburg.

Dijkstra, W. 1898-1911: Friesch Woordenboek, Leeuwarden.

Franck, J. and N. van Wijk 1912: Etymologisch woordenboek der Nederlandsche taal, tweede druk, 's-Gravenhage.

van Ginneken, J. 1938: Sp-kaarten, Onze Taaltuin 7, 112-113.
Goossens, J. 1963: Semantische vraagstukken uit de taal van het landbouwbedrif in Belgisch-Limburg, Antwerp.

Goossens, J., J. Taeldeman en G. Verleyen 1998: Fonologische Atlas van de Nederlandse Dialecten. Deel I, Gent.

Grimm, J. and W. Grimm 1893: Deutsches Wörterbuch. Achter Band: R-Schiefe. Bearbeitet von und unter Leitung von Dr. Moriz Heyne, Leipzig.

van Haeringen, C.B. 1936: Supplement to Franck-van Wijk 1912, 's-Gravenhage.

von Keller, A. and H. Fischer 1920: Schwäbisches Wörterbuch, fifth volume, Tübingen.

Kiliaan = Kilianus Dufflaeus, C. 1599: Etymologicum teutonicae linguae sive dictionarium teutonico-latinum, 3a ed., Antwerp.

Klees, H. 1981: Luxemburger Tiernamen ${ }^{2}$ (= Beiträge zur luxemburgischen Sprachund Volkskunde 14), Luxembourg.

Kluge, F. 1915: Etymologisches Wörterbuch der deutschen Sprache. Achte verbesserte und vermehrie Auflage, Strassburg.

Kortlandt, F. 1991: Kluge's law and the rise of Proto-Germanic geminates, Amsterdamer Beiträge zur älteren Germanistik 34, 1-4.

Kuiper, F.B.J. 1995: Gothic bagms and Old Icelandic ylgr, NOWELE 25, 63-88.

Lühr, R. 1988: Expressivität und Lautgesetz im Germanischen, Heidelberg.

Martin, E. and H. Lienhart 1907: Wörterbuch der elsässischen Mundarten, second volume, Strassburg.

Maurer etc. 1978-1985: Hessisch IV: $K u$ - R, Marburg.

Mitzka, W. 1964: Schlesisches Wörterbuch, second volume, Berlin.

Müller, J., M. Zender, H. Dittmaier, K. Meisen (ed.) 1948-58: Rheinisches Wörterbuch, seventh volume, Berlin.

Plantijn, C. 1573: Thesaurus Theutonicae Linguae. Schat der Nederduytscher spraken, Antwerp.

Pokomy, J. 1959: Indogermanisches Etymologisches Wörterbuch, Tübingen Basel.

Riemann, E., R. Goltz and U. Tolksdorf 1992: Preussisches Wörterbuch, Neumünster.

Schrijver P. 1997: Animal, vegetable and mineral: some Westem European substratum words, in Sound Law and Analogy. Papers in honor of Robert S. Beekes on the occasion of his 60th birthday (edited by Alexander Lubotsky), 293-316.

Spangenberg, K. a.o. 1982: Thüringisches Wörterbuch, fifth volume, Berlin.

Staub, F., L. Tobler, A. Bachmann and others 1909: Schweizerisches Idiotikon: Wörterbuch der schweizerdeutschen Sprache, sixth volume, Frauenfeld.

van Sterkenburg, P. 1973: Verkenningen in middeleeuwse lexicografie naast een onderlinge relatie, Leuvense Bijdragen 62, 3-36.

Stevens, A. 1986: Túngërsë Dïksjënêer, Tongeren.

Teuthonista = G. van der Schueren, Teuthonista of Duytschlender, Cologne 1477 [ed. J. Verdam, Leiden 1896].

de Vaan, M. 1997: 'Suiker' in de Limburgse dialecten en de ontwikkeling van WGm. ${ }^{*} u$ in gesloten syllabe, Taal en Tongval 49, 115-138.

de Vries, J. 1971: Nederlands etymologisch woordenboek, Leiden

van de Water, A. 1904: De volkstaal in het oosten van de Bommelerwaard, Utrecht. von Wartburg, A. 1940: Französisches Etymologisches Wörterbuch II/1, ccohortile, Leipzig-Berlin.

$W B D=$ Woordenboek van de Brabantse dialecten, Assen 1967ff.

Weijnen, A. 1937: Onderzoek naar de dialectgrenzen in Noord-Brabant, Fijnaart. 1966: Nederlandse Dialectkunde, Assen. 
van dc Wouw, J.G.W. 1968: Dialektgeografie van het Weertlands en zijn onmiddellijke omgeving, aan de hand van een monografie over het Nederweerts. Doctoraalscriptie. Nijmegen.

Wissmann, W. 1975: Die altnordischen und westgermanischen Nomina postverbalia, Heidelberg.

Wossidlo, R. and H. Teuchert 1970: Mecklenburgisches Wörterbuch, fifth volume Neumünster.

Young, G.V.C. and C.R. Clever 1985: Faroese-English dictionary, Peel (Isle of Man).

\section{Postscript}

After I had received the proofs of my manuscript, I was sent the text of the article 'Rupseme hetet in onse tale': Van ruip en rups, which Jan B.

Berns has just published in the volume 'Met taal om de tuin geleid. Een bundel opstellen voor Georges De Schutter ter gelegenheid van zijn pre-emeritaat' (Antwerp, reprografie UIA, 2000), p. 19-24. He gives a more extensive list of MiDutch attestations, and stresses the existence of different dialect forms. His historical explanation, viz. that the oldest form was $\mathrm{Gm}$. *rûpanô, which was replaced by *rûp-smanô (Flemish rupsem), whence by suffix reduction modern rups, can be dismissed using the data I have presented. 